\title{
A Mini-reactor for Glucose Analysis in Human Serum Samples
}

Flavio M. Lopes, Sydnei Mitidieri \& Kátia F. Fernandes

Este trabalho apresenta o desenvolvimento de um mini-reator contendo glicose oxidase e peroxidase imobilizadas em polianilina/glutaraldeído (PANIG), que foi utilizado para determinação de glicose em amostras de soro humano. A imobilização de GOx resultou em rendimento de $16 \%$. Três modelos de reatores foram testados e o de leito fluidizado apresentou melhor desempenho. Neste, a faixa linear da determinação ficou entre 0,5 a $6,0 \mathrm{mg} \mathrm{mL}-1$, com excelente reprodutibilidade ( $\mathrm{RSD}=0,003$ ). Os resultados obtidos no mini-reator foram comparados com os obtidos com enzimas livres e analisados estatisticamente com o teste t pareado num intervalo de confiança de $95 \%$ para validação.

Palavras-chave: mini-reator; glicose; glicose oxidase; imobilização; polianilina.

This work presents the development of a mini-reactor with glucose oxidase and peroxidase immobilized onto polyaniline/glutaraldehyde (PANIG), which was used for glucose determination in human serum samples. Immobilization of GOx yields $16 \%$. Three reactor designs were tested, and the fluidised ascendant bed reactor showed the best performance. In this reactor the linear range for glucose determination was 0.5 to 6.0 $\mathrm{mg} \mathrm{mL}-1$, with excellent reproducibility of response $(\mathrm{RSD}=0.003)$. The results obtained in the mini-reactor were compared with those obtained using free enzymes and then analysed statistically with a paired $t$ test $(95 \%$ confidence interval) for validation.

Keywords: mini-reactor; glucose; glucose oxidase; immobilization; polyaniline. 


\section{Introduction}

Glucose concentration is one of the most important factors in the diagnosis of several diseases ${ }^{1}$. The development of rapid, inexpensive, sensitive and selective methods for detection of this compound is an endeavour that has concentrated efforts from areas such as chemistry and clinical analysis ${ }^{2}$.

Several studies have described the development of devices for glucose determination, most of then conductimetric and amperometric biosensors that use immobilised glucose oxidase (GOx) and horseradish peroxidase (HRP). These biosensors have very high sensitivity, and several are designed for flow injection analysis $^{3,2,4,5,6,7}$.

Although less frequently used, spectrophotometric methods are simple and rapid, and the necessary equipment is widely available. We have recently described a spectrophotometric system for hydrogen peroxide determination that yielded high sensitivity $\left(55 \mathrm{nmol} \mathrm{L}^{-1}\right)$ and very high stability (1500 injections) $)^{8}$. In this study, we describe a very simple device that can be coupled to a spectrophotometer to provide a simple and rapid method of glucose determination. This system, composed of GOx and HRP immobilized onto polyaniline activated by glutaraldehyde (PANIG), may be used 25 times without significant variations in sensitivity to glucose when analysing samples of human serum.

\section{Methodology}

\section{REAGENTS}

Type VI horseradish peroxidase (HRP) was purchased from Sigma Chemical Co. (St. Louis, MO, US). Glucose oxidase (GOx; $90 \mathrm{U} \mathrm{mg}^{-1}$ ), hydrogen peroxide and aniline were obtained from E. Merck (Darmstadt, Germany). Aniline was distilled under vacuum to obtain a colourless liquid. All other reagents were analytical grade and were used without further purification. Solutions were prepared with deionised water.

\section{POLYMER SYNTHESIS AND ACTIVATION}

Polyaniline (PANI) was chemically synthesised as described previously ${ }^{9}$ using ammonium persulfate as the oxidising agent. The black/green powder obtained was activated with a $2.5 \%(\mathrm{v} / \mathrm{v})$ glutaraldehyde solution under reflux for $2 \mathrm{~h}$, to obtain glutaraldehyde-activated polyaniline (PANIG). After abundant washing with $0.1 \mathrm{~mol} \mathrm{~L}^{-1}$ phosphate buffer $(\mathrm{pH} 6.0)$, the powder was dried under dynamic vacuum and stored at room temperature until its use for enzyme immobilisation.

\section{IMMOBILISATION AND ASSAY}

The immobilisation of HRP was carried out as described previously ${ }^{9}$, and 16.2 U HRP mg-1 PANIG was obtained, which represents a $24.5 \%$ yield. Immobilisation of glucose oxidase (PANIG-GOx) was optimised by varying enzyme and polyaniline (PANIG) concentration, $\mathrm{pH}$, and immobilisation reaction time.

Following a standard assay procedure, $2.8 \mathrm{~mL}$ of a freshly prepared solution of $41.05 \mathrm{mmol} \mathrm{L}^{-1}$ phenol and $0.6 \mathrm{mmol} \mathrm{L}^{-1} 4$-aminoantipyrine, both prepared in $0.1 \mathrm{~mol}$ $\mathrm{L}^{-1}$ sodium phosphate buffer ( $\mathrm{pH} 7.0$ ), was added to the immobilised enzyme derivatives. The addition of $20 \mu \mathrm{L}$ of glucose solution started the reactions, which were allowed to proceed for $10 \mathrm{~min}$. After that, the resulting product was analysed in a spectrophotometer at $510 \mathrm{~nm}$.

\section{REACTOR DESIGN}

Three types of reactors were tested: sequential packed bed PANIG-GOx/PANIG-HRP reactors, consisting of two coupled reactors; a single packed bed PANIGGOx-HRP reactor; and a fluidised bed PANIG-GOx and PANIG-HRP reactor. Their performance for glucose determination was tested, and the fluidised bed reactor was chosen for this study.

The fluidised bed reactor consisted of $5.0 \mathrm{mg}$ of PANIG-HRP and 5.0mg of PANIG-GOx assembled into a polypropylene reaction chamber connected to an air pump. The chamber had a connection for substrate input at the top and a valve for product exit at the bottom. The products were pumped through a detection system that consisted of a spectrophotometer connected to a recorder that obtained optical density at each 5 sec. Optical detection was measured at $510 \mathrm{~nm}$ with a glass cell of 1.0 mm optical path length.

The rate of PANIG-HRP and PANIG-GOx concentrations in the reaction chamber was tested to obtain the best performance of the system.

Operational range for glucose determination and 
operational stability of the mini-reactor

The system was operated at room temperature. The operations consisted of filling the reaction chamber, which already contained the immobilised enzymes, with $2.8 \mathrm{~mL}$ of a freshly prepared solution of $41.05 \mathrm{mmol}$ $\mathrm{L}^{-1}$ phenol and $0.6 \mathrm{mmol} \mathrm{L}^{-1}$ 4-aminoantipyrine, both prepared in $0.1 \mathrm{~mol} \mathrm{~L}^{-1}$ sodium phosphate buffer $(\mathrm{pH}$ 7.0). The addition of $20 \mu \mathrm{L}$ of glucose solution started the reaction, which proceed for $10 \mathrm{~min}$. The exit valve was then opened, and the product formed was pumped to the detector system. Residence times of 1 to $30 \mathrm{~min}$ were tested. The operational range for glucose concentration was tested from 2.78 to $33.33 \mu \mathrm{mol} \mathrm{L}^{-1}$. Readings greater than $0.4 \mathrm{U}$ were classified as the lower limit of detection, and readings below this value were classified as noise.

The operational stability of the mini-reactor was tested by sequential injections of glucose samples followed by washes with phosphate buffer.

Determination of glucose in human serum samples

The human serum samples were collected and prepared for glucose analysis in a clinical analysis laboratory (CADI Laboratory). Glucose was analysed using commercial kits with free GOx and HRP and phenol and 4-aminoantipyrine substrates. Aliquots of the human serum samples were placed in cooled containers and then sent to our laboratory for glucose determination in the mini-reactor. The results obtained in both glucose analyses were compared. The tests in the mini-reactor were performed in triplicates, and the results were described as mean and standard deviation. The values obtained with the commercial kit and the mini-reactor were analysed statistically using a paired $t$ test at $95 \%$ confidence interval to validate our measurements.

\section{Results and Discussion}

\section{GOX IMMOBILISATION}

Immobilisation parameters were optimised for GOx, and maximum immobilisation yield was $16 \%$ when 5.0 $\mathrm{mg}$ of PANIG and $8.9 \mathrm{U}$ prepared in $0.1 \mathrm{~mol} \mathrm{~L}^{-1}$ sodium phosphate buffer $\left(\mathrm{pH} 7.0\right.$ ) reacted for $60 \mathrm{~min}$ at $4^{\circ} \mathrm{C}$ under gentle stirring. Figure 1 shows that $\mathrm{pH}$ seems to be the most important immobilization factor: variations of one $\mathrm{pH}$ unit resulted in large increases of the amount of immobilised enzyme. The best results were obtained at $\mathrm{pH} 7.0$ and 8.0.

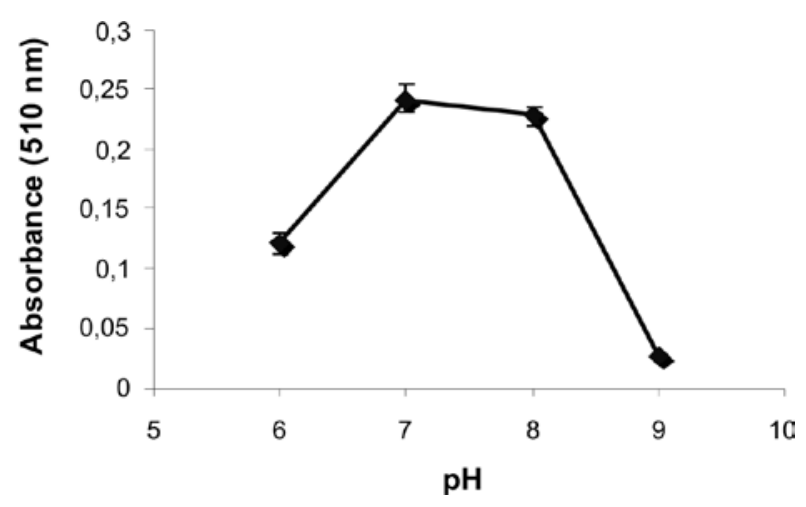

Figure 1: Activity of immobilised GOD as a function of $\mathrm{pH}$.

Reaction time and enzyme concentration had very similar effects on immobilisation. Initial increases in reaction time or enzyme concentration resulted in increases of the amount of immobilised enzyme up to a limit over which the activity of the derivative containing the immobilised enzyme decreased (figures $2 \mathrm{~A}$ and 2B). This finding may be explained by the formation of a multilayer of immobilised enzymes due to excessive enzyme concentration or exposure time ${ }^{10,11}$.

\section{REACTOR DESIGNS}

The main restriction to the use of sequential reactors was the difference in residence time. While the reactor with PANIG-GOx required a 10-min reaction, the PANIG-HRP reactor required only $1 \mathrm{~min}$ for hydrogen peroxide determination. This characteristic of the enzymes complicated the development of a reactor for flow analysis.

The use of the packed bed reactor with PANG-GOxHRP revealed an interesting characteristic of the enzyme immobilisation processes. When $10 \mathrm{mg}$ of PANIG were left to react with a solution containing the optimised concentrations of GOx and HRP, the immobilisation rates were $98 \%$ GOx and $1.7 \%$ HRP. GOx seemed to have about 100 times greater affinity for PANIG bonding than HRP. Under such conditions, it would be necessary to increase the amount of HRP in the immobilisation solution to compensate for GOx affinity and to obtain an optimised rate of enzymes for glucose determination. 


\section{Artigo 6}

Varying amounts of PANIG-GOx and PANIG-HRP were tested to avoid HRP destruction by hydrogen peroxide produced by the GOx reaction. We found that peroxidase inactivation was absent up to $0.33 \mathrm{mmol} \mathrm{L}^{-1}$ hydrogen peroxidase, which is in agreement with findings reported by Fernandes et al $(2005)^{8}$.

The best results were obtained in the fluidised bed reactor, which was used in this study.

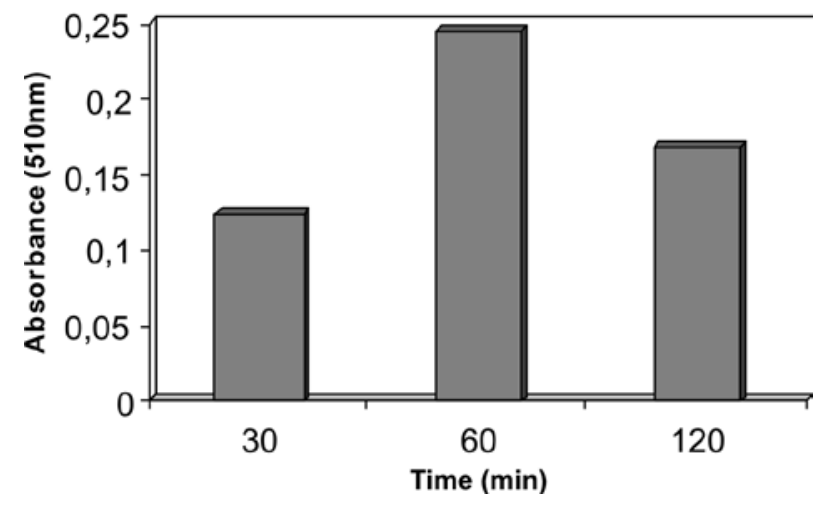

(A)

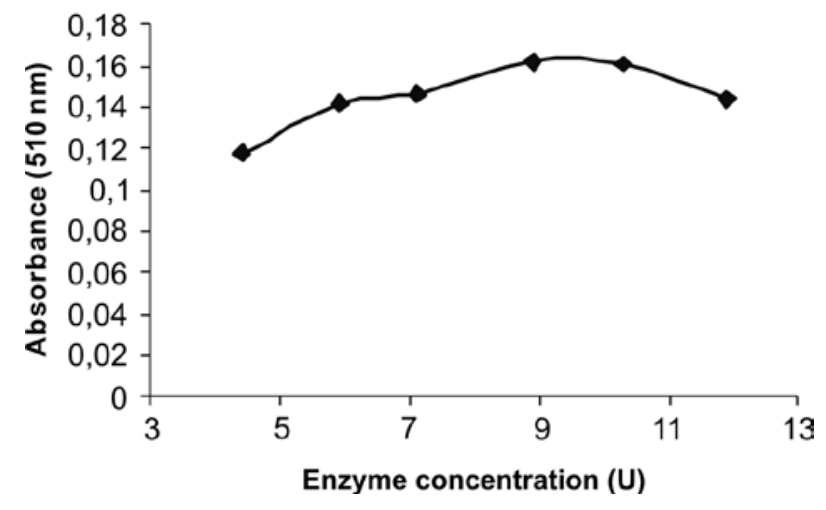

(B)

Figure 2A: Activity of immobilised GOD as a function of reaction time; Figure 2B: Activity of immobilised GOD as a function of enzyme concentration.

\section{OPERATIONAL RANGE FOR GLUCOSE DETERMINATION}

Figure 3 shows the mini-reactor response to various concentrations of glucose. The system was able to determine glucose from 2.8 to $33.3 \mu \mathrm{mol} \mathrm{L} \mathrm{L}^{-1}$. This range corresponds to $50-600 \mathrm{mg} \mathrm{dL}^{-1}$, values which cover the range of hypoglycaemic and hyperglycaemic states.

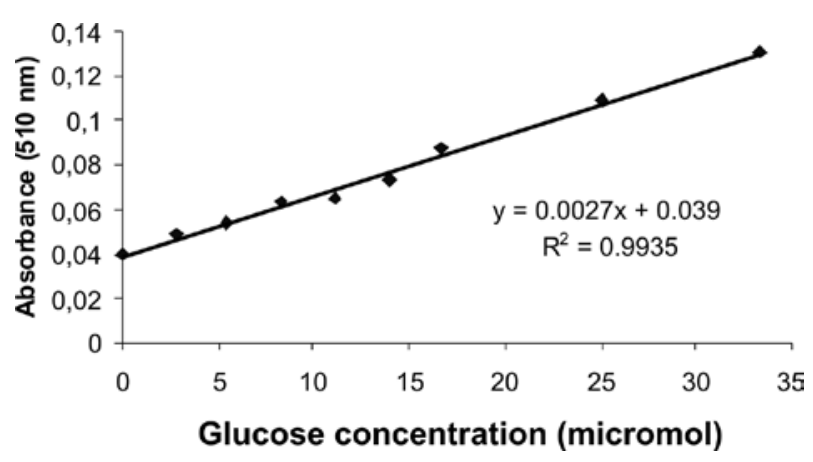

Figure 3: Linear range of glucose detection. Inferior detection limit $=$ $2.2 \mu \mathrm{mol}\left(50 \mathrm{mg} \mathrm{dL}^{-1}\right)$; superior detection limit $=33.3 \mu \mathrm{mol}(600 \mathrm{mg}$ $\left.\mathrm{dL}^{-1}\right)$.

This system also showed good reproducibility of responses. Figure 4 shows that the peaks obtained for three independent injections were very similar, both in area and in shape.

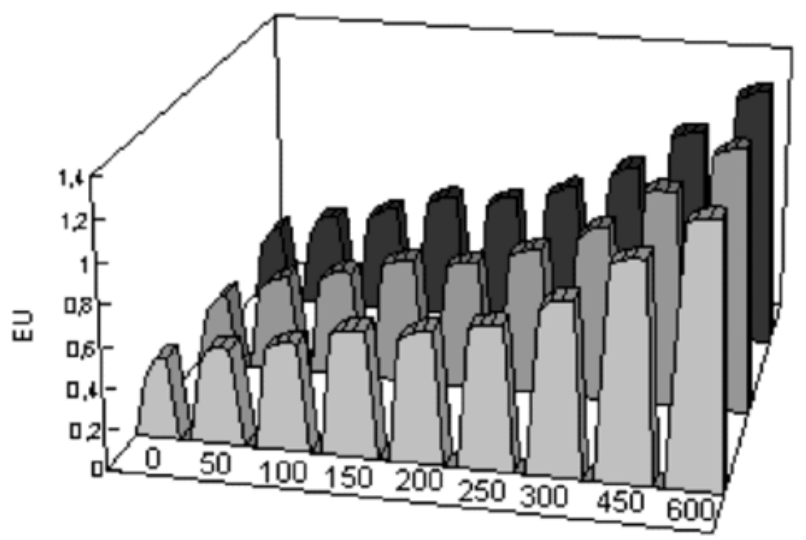

\section{Glucose concentration ( $\mathrm{mg} \mathrm{dL}^{-1}$ )}

Figure 4: Spectrophotometric response for three glucose consecutive injections in the mini-reactor.

The mini-reactor also showed high operational stability. Figure 6 shows the response of the mini-reactor for independent injections of glucose. It was possible to use the mini-reactor for glucose determination 25 times without any loss in sensitivity (Figure 5). Gürsel el al 
(2003)12 reported a biosensor for glucose which was stabilized after five cycles of use and retained about $50 \%$ of the initial activity for the remaining 25 cycles.

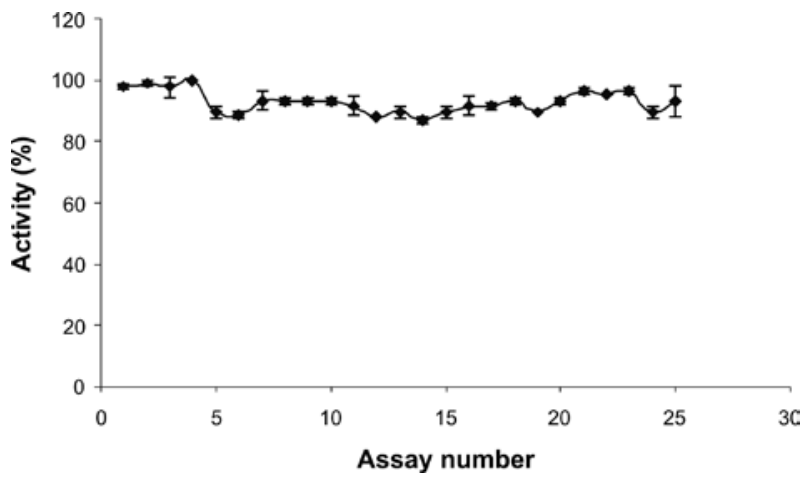

Figure 5: Repeated use of the mini-reactor. The results are presented as percentage of remained activity versus assay number.

\section{DETERMINATION OF GLUCOSE IN HUMAN SERUM}

Table 1 shows the results of glucose determination in human serum by clinical laboratory analysis using commercial enzymatic kits (glucose oxidase and peroxidase) and by using the mini-reactor for the same samples. Results showed no statistically significant differences (paired t test).

\section{Conclusion}

Polyaniline is an inexpensive and very stable polymer that can be synthesized by a simple and rapid procedure. Glucose oxidase (GOx) and horseradish peroxidase (HRP) were covalently fixed onto this polymer via glutaraldehyde. The immobilised enzyme assembled in a polypropylene chamber resulted in a device that can be coupled to a spectrophotometer and used for glucose determination. The operational range for glucose determination was 2.8 to $33.3 \mu \mathrm{mol} \mathrm{L}^{-1}$ (50 $600 \mathrm{mg} \mathrm{dL}^{-1}$ ), which covers the glucose concentrations of hypoglycaemic and hyperglycaemic states.

This device showed very good reproducibility of response and high operational stability. It was used for 25 cycles of glucose determination without loss in sensitivity. Glucose concentrations in human serum samples were determined with the same sensitivity as that obtained with commercial kits that use free enzymes, as statistically demonstrated by the results of the paired $t$ test at $95 \%$ confidence interval.

\section{Acknowledgments}

The authors thank Dr. Wander Cairo Albernaz for kindly providing the enzyme glucose oxidase, and Ms. Rhalcia Cristina de Melo, MSc (clinical analysis laboratory - CADI).

Table 1: Glucose values from mini-reactor and clinical laboratory.

\begin{tabular}{|c|c|c|}
\hline $\begin{array}{c}\text { Clinical } \\
\text { laboratory } \\
\text { Values }\left(\mathrm{mg} \mathrm{dL}^{-1}\right)\end{array}$ & $\begin{array}{c}\text { Mini-reactor } \\
\text { Values } \\
\left(\mathrm{mg} \mathrm{dL}^{-1}\right)\end{array}$ & $\begin{array}{l}\text { Relative } \\
\text { Standard } \\
\text { Deviation }\end{array}$ \\
\hline 82 & $81.9 \pm 2.17$ & 0.02 \\
\hline 96 & $127.7 \pm 4.20$ & 0.03 \\
\hline 73 & $73.3 \pm 2.17$ & 0.03 \\
\hline 86 & $94.1 \pm 2.17$ & 0.02 \\
\hline 84 & $69.4 \pm 3.90$ & 0.05 \\
\hline 96 & $93.0 \pm 5.50$ & 0.06 \\
\hline 79 & $78.1 \pm 2.17$ & 0.03 \\
\hline 98 & $91.3 \pm 5.50$ & 0.06 \\
\hline 118 & $93.8 \pm 5.50$ & 0.06 \\
\hline 90 & $89.1 \pm 3.90$ & 0.04 \\
\hline 99 & $91.6 \pm 1.26$ & 0.01 \\
\hline 103 & $91.8 \pm 2.17$ & 0.02 \\
\hline 119 & $88.4 \pm 3.90$ & 0.04 \\
\hline 70 & $84.3 \pm 4.20$ & 0.05 \\
\hline 75 & $80.0 \pm 5.50$ & 0.06 \\
\hline 100 & $104.4 \pm 4.90$ & 0.05 \\
\hline 88 & $82.0 \pm 4.70$ & 0.06 \\
\hline 86 & $85.5 \pm 1.60$ & 0.02 \\
\hline 82 & $82.5 \pm 2.30$ & 0.03 \\
\hline 96 & $93.4 \pm 6.40$ & 0.07 \\
\hline 88 & $86.5 \pm 2.60$ & 0.03 \\
\hline
\end{tabular}




\section{REFERENCES}

1. Barone, P.W.; Parker, R.S.; Strano, M.S.; Anal. Chem. 2005, 77, 7556.

2. Salomi, S.; Compton, R.G.; Hallaj, R.; Analytical Biochemistry. 2004, 333, 49.

3. Chaubey, G. M.; Malhotra B.D.; Biosensors \& Bioelectronics. 2002, 17, 345.

4. Du, Y.; Luo, X.L. ; Xu, J.J. ; Chen, H.Y. ; Bioelectrochemistry. 2007, 70, 342.

5. Wu, B.Y; Hou, S.H.; Yin, F.; Li, J.; Zhao, Z.X.; Huang, J.D.; Chen, Q.;. Biosensors and Bioelectronics. 2007, 22,838 .

6. Gamburzev, S.; Atanasov, P.1.; Ghindilis, A.L.; Wilkins, E.; Kaisheva, A.I.; Sensors and Actuators B. 1997, 43, 70.

7. Barsan, M.M.; Klincar, J.; Batic, M.; Brett, C.M.A.; Talanta. 2007, 71, 1893.

8. Fernandes, K.F.; Lima, C.S; Lopes, F.M.; Collins, C.H.; Process Biochemistry. 2005, 40, 3441.

9. Fernandes, K.F.; Lima, C.S.; Pinho, H.; Collins, C.H.; Process Biochemistry. 2003, 38, 1379.

10. Costa, S.A.; Tzanov, T.; Paar, A.; Gudelj, M.; Gübitz,
G.M.; Cavaco-Paulo, A.; Enzyme Microb Tech. 2001, 28,815 .

11. Caramori, S.S.;Fernandes, K.F.;Process Biochemistry. 2004, 39, 883.

12. Gürsel, A.; Alkan, S.; Toppare, L.; Yagci, Y.; Reactive \& Functional Polymers. 2003, 57, 57.

\section{Flavio Marques Lopes', Sydnei Mitidieri ${ }^{2}$ and Kátia Flávia Fernandes* ${ }^{*}$.}

${ }^{1}$ Laboratório de Química de Proteínas, Departamento de Bioquímica e Biologia Molecular, Instituto de Ciências Biológicas, Universidade Federal de Goiás, Cx. Postal 131, CEP 74001-970 Goiânia, GO, Brazil. Fone +55-02162 - 3521 $1492 \mathrm{Fax}+55-02162-35211190$.

${ }^{2}$ BioPlus Desenvolvimento Biotecnológico LTDA - Incubadora Empresarial IECbiot, Universidade Federal do Rio Grande do Sul, P.O. Box 15027, CEP 91501-970, Porto Alegre, RS, Brazil

*E-mail: katia@icb.ufg.br 